\title{
External Locus of Control and Demographic Data as Determinant Factors of Trauma Resilience: A Study among Young Women Who Were Exposed to Violence
}

\author{
Alfina Rizkia ${ }^{1}$, Chandradewi Kusristanti ${ }^{2}$ \\ 1,2Fakultas Psikologi Universitas YARSI; Jl.Letjend Suprapto No.Kav. 13, Cempaka Putih, \\ Jakarta Pusat 10510, (021) 4223138/(021) 4223138 \\ e-mail: *1alfinarizkia21@gmail.com
}

Received: $9^{\text {th }}$ July 2020/ Revised: $3^{\text {rd }}$ November 2020 /Acceptep $29^{\text {th }}$ December 2020

\begin{abstract}
The number of violent incidents on women is increasing every year in Indonesia. Some women can survive through traumatic experiences, and it is related to their resilience. Locus of control (LoC) is known to contribute to resilience by enhancing individuals' selfcontrol and problem-solving behavior. This study aims to determine the role of LoC in trauma resilience among 134 young women (20 - 40 years old) who were exposed to violence (domestic, physical, and sexual) and a minimum of high school education. This study used a quantitative approach with the Locus of Control Scale ( $\alpha=0.732,18$ items) and the Trauma Resilience Scale ( $\alpha=0.961,48$ items). Two hypotheses are proved in this study: (1) external LoC significantly contributes to trauma resilience $\left(p=.000, R^{2}=.139\right)$, (2) there is a significant difference between violence exposure (<.001), perpetrators (.005), and disclosure to others about their experience of violence (.009). We also found that no participants reported a dominant internal LoC, so future studies are advised to focus on women who were exposed to violence with a more dominant internal LoC.

Keywords: Locus of Control; Trauma Resilience; Young Women; Violence Survivors.

Abstrak. Angka kasus kekerasan pada wanita di Indonesia meningkat setiap tahunnya. Terdapat wanita yang dapat bertahan dari pengalaman kekerasan yang mereka alami, salah satu penyebabnya ialah adanya resiliensi. LoC diketahui dapat berkontribusi terhadap resiliensi dengan meningkatkan kontrol individu serta kemampuan pemecahan masalah. Penelitian ini bertujuan untuk mengetahui peran LoC terhadap resiliensi trauma pada 134 wanita dewasa muda (20 - 40 tahun) yang pernah terpapar kekerasan (KDRT, fisik dan seksual) dan minimal pendidikan terakhir SMA. Penelitian ini menggunakan pendekatan kuantitatif dengan Locus of Control Scale $(\alpha=0.732,18$ aitem) dan Trauma Resilience Scale ( $\alpha=0.961,48$ aitem). Dua hipotesis terbukti dalam penelitian ini, yaitu (1) LoC eksternal memiliki peran yang signifikan terhadap resiliensi trauma $\left(p=.000, R^{2}=.139\right)$, dan (2) terdapat perbedaan yang signifikan pada paparan kekerasan (<.001), pelaku (.005) dan menceritakan pengalaman kekerasan (.009). Dalam penelitian ini, kami juga menemukan tidak ada partisipan yang memiliki dominan LoC internal, sehingga untuk penelitian selanjutnya diharapkan untuk dilakukan pada wanita korban kekerasan yang memiliki dominan LoC internal.
\end{abstract}

Kata kunci: Locus of Control; Resiliensi Trauma; Wanita Dewasa; Penyintas Kekerasan 


\section{RIZKIA \& KUSRISTANTI}

Violence incidents experienced by both women and men can cause trauma or other harmful psychological conditions. In this research, we will discuss and explain the trauma of violent incidents on women because Thureau, Blanc-Louvry, Thureau, Gricourt, and Proust (2015) stated that psychological impacts of violence are more frequently found in women than men. Women who were exposed to violence, whether they directly experienced, witnessed violence, or both, have the opportunity to experience trauma, but the impact of trauma will usually be different (Moya, 2018). Based on the World Health Organization's (2017) data, around 35\% of women worldwide have experienced violence, both physical and sexual violence. In Indonesia, the number of violence against women cases reported by the National Commission on the Elimination of Violence (Komnas Perempuan) consistently increasing from year to year.

Carlson and Dalenberg (2000) mentioned that trauma could cause responses and negative impacts on victims of violence, including depression, aggression caused by feelings of frustration, drugs, physical illness, decreased self-esteem, identity confusion, guilty and ashamed feeling, and several problems in interpersonal relationship. In the same study, it was also explained that mental health disorders among women victims of violence would have a significant impact on themselves and the environment, such as their decreased productivity. Alho (2015) stated that women's violence victims often lack social competence and are not ready to participate in social activities. Collins and Swearer (2012) also said that women's violence victims tend to have difficulty focusing on learning. Therefore, it can be concluded that psychological conditions in women victims of violence will have some negative impacts on themselves and those around them.

Although there are many negative impacts of violence, Anderson, Renner and Danis (2012) explained that women who were exposed to violence and possessed strong resilience usually do not feel suffering due to violence experienced. In fact, they will help themselves and other victims to rebuild their lives through self-awareness and their interpersonal relationship. All in all, we argued that trauma resilience is very important to be investigated. 
As previously mentioned, there are many negative impacts caused by violence. Those negative impacts include physical and psychological impacts for women victims of violence. Although there are many negative impacts of trauma in women victims of violence, other women can recover from the traumatic events they experienced. Anderson, Renner and Danis (2012) stated that women victims of violence could recover and successfully leaving unhealthy relationships, including violent relationships, even when they experienced violence for years. A relatively stable resilience is believed to play a role in that critical decision.

Resilience usually refers to positive adaptation to maintain mental health and includes some factors to support it, which are personal factors, biological factors, environmental factors, and also interactions between personal, genetic, and environmental factors (Herman, Stewart, Diaz-Granados, Berger, Jackson, \& Yuen, 2011). The same study also explained that resilience is related to individuals as well as their society's characteristics. Resilience is mostly related to events that usually cause distress, such as trauma, academic problems, and other events.

A concept of resilience, precisely due to trauma, is called trauma resilience. Madsen and Abell (2010) stated that trauma resilience is a combination of phenomena that can make a person return to their functional status after experiencing a violent event. Madsen and Abell (2010) also focus on protective factors that can improve adaptation ability in individuals when experiencing situations that can cause stress; one of the experiences is violence. According to the American Psychological Association (2019), protective factors could reduce the likelihood of poor mental health. Protective factors are also said to help maintain a stable mental state in individuals and make them resilient.

One of the protective factors of resilience is locus of control (LoC) (Domhardt, Münzer, Fegert, \& Goldbeck, 2015). LoC theory was first explained by Rotter (1966). Rotter (1966) explained that LoC is divided into two categories: internal and external LoC. Internal LoC is a condition where individuals feel an event that comes to them are depends on their behavior. Meanwhile, external LoC 


\section{RIZKIA \& KUSRISTANTI}

can be explained as a condition where an individual feels an event that comes to them are from external factors, such as parents and God. Both internal and external LoCs must be present in individuals, but one of them will be more dominant (Rotter, 1966). Huntley, Palmer, and Wakeling (2012) then constructed a measurement of LoC, derived from Rotter's theory. We then used the LoC Scale from Huntley, Palmer, and Wakeling (2012) in this study.

A study from Cazan and Dumitrescu (2016) showed that the existence of $\mathrm{LoC}$ and resilience in an individual could help him/ her to solve the conflict better. Hood and Carter (2008) found that internal LoC has a significant role in resilience. Individuals who have more dominant internal LoC will have the ability to exercise personal control over their environment and be more able to control their lives. A research conducted by Valentine and Feinauer (2007) on women who experienced sexual violence during their childhood found that internal LoC is one of several factors that can help participants survive from their traumatic experience. Meanwhile, Asberg and Renk (2012) found that individuals who have more dominant in external LoC, if related to the context of getting intervention because of their traumatic experiences, will be more comfortable accepting these interventions than individuals with a more dominant internal LoC. This is because they consider the therapists a social support resource that they have not been getting before.

From earlier studies mentioned above, they mostly explained that only internal LoC that have a positive effect on women who were exposed to violence. In this study, we want to investigate about both LoC in determining trauma resilience. Furthermore, several studies mentioned that the participants' demographic data could be some determinant factors, so we also explore more about demographic data in this study. This study used young women as their sample. Several studies found that trauma resilience grows along with ages (Jamison, 2016; Burt \& Paysnick, 2012). Resilience is expected to survive along with the transition to adulthood; it is hoped that people have already completed their previous developmental tasks (Masten, Roisman, Obradović, Long, \& Tellegan, 2004). To conclude, this study aims to determine the role of internal and external LoC in trauma resilience among 
young women who were exposed to violence and investigate the demographic data.

This study has two hypotheses: (1) LoC contributes significantly to trauma resilience, and (2) There is a significant difference between demographic factors and trauma resilience. Referring to the increasing number of violence cases against women from year to year, this study aims to look at the role of LoC in trauma resilience in young women who have experienced or witnessed violence and investigate the difference between demographic data and trauma resilience. If the results of this study showed a significant role in LoC for trauma resilience, the results could be used to establish an effective intervention for young women who were once exposed to violence.

\section{Methods}

\section{Research Participants}

Participants were young women (20-40 years old) who have experienced or witnessed violence during their childhood, teenage, or young adult period. According to Madsen and Abell (2010), violence is categorized as physical violence, sexual violence, intimate partner violence, or severe threat or injuries.
Minimum education of high school is also another requirement to participate in this study. This research was conducted for approximately a year, from 2018 until 2019. We used accidental sampling and distributed questionnaires using Google Forms to recruit participants $(\mathrm{N}=134)$.

\section{Research Instruments}

This study used two questionnaires: Locus of Control Scale (LoC Scale) (Huntley, Palmer, \& Wakeling, 2012) and Trauma Resilience Scale (TRS) (Madsen \& Abell, 2010). Both questionnaires were distributed online. There are 18 items with a 5-point Likert scale in LoC Scale, ranging from 0 (strongly disagree) to 4 (strongly agree). There are seven favorable items (example: I can anticipate difficulties and take action to avoid them) and 11 unfavorable items (example: A great deal of what happens to me is just a matter of chance). For TRS, there are 48 items with 13 items to indicate supportive relationship (example: I have very close friends), 12 items indicating optimism (example: Most people say that I have a hopeful outlook on life), ten items indicating problem-solving ability (example: I can achieve the goals I set for myself), and 13 


\section{RIZKIA \& KUSRISTANTI}

items to indicate spirituality (example: $I$ meditate or pray regularly). Each TRS item is scored using a 7-point Likert scale, which indicates a frequency, ranging from 'rarely true of me' (1) to 'almost always true of me' (7).

Before we distributed the questionnaires to the actual sample, we did a try out $(\mathrm{N}=30)$. In try out phase, we then tested both measurements' reliability using Cronbach Alpha. It was found that the LoC Scale and the TRS are reliable to use, with the score of .732 and .961, respectively. The item analysis and validity test results using face validity and content validity also show that both questionnaires were valid enough to be used. No item should be revised.

Besides those two questionnaires, we also constructed a questionnaire that includes the history of violence experienced by participants, with a few short questions that participants must answer. This questionnaire contains matters related to violence experienced by participants, which became our demographic data that we process to investigate the differences; such as the type of violence, the age of exposure to violence, the frequency of exposure to violence, perpetrators of violence, and whether or not they have undergone postviolence treatment. The questionnaire will be filled in by participants who fit the criteria. The results of this questionnaire will then be used to test the second hypothesis.

\section{Data Analysis}

We used simple regression to investigate the role of LoC on trauma resilience. We also used a T-test to analyze the demographic data that only have two options on the answer and use One Way-ANOVA to analyze the demographic data with more than two options.

\section{Result}

The majority of participants in this research are those who both experienced and witnessed the violence. There are more participants than experienced domestic violence, and the first exposure is in their childhood. More than half of the participants experienced violence more than once by somebody they know. Most of the violence is already over, and most have not accessed post-incident treatments, yet they mostly told other people about the violent incidents they were exposed to, please refer to Table 1. 
Table 1

Demographic Data

\begin{tabular}{|c|c|c|}
\hline Variable & Participants & Percentage \\
\hline \multicolumn{3}{|l|}{ Violence Exposure } \\
\hline Experienced & 25 & $18.6 \%$ \\
\hline Witnessed & 54 & $40.3 \%$ \\
\hline Experienced \& Witnessed & 55 & $41.1 \%$ \\
\hline \multicolumn{3}{|l|}{ Type of Violence } \\
\hline Domestic Violence & 68 & $50.7 \%$ \\
\hline Physical Violence & 46 & $34.4 \%$ \\
\hline Sexual Violence & 20 & $14.9 \%$ \\
\hline \multicolumn{3}{|l|}{ First Exposure to Violence } \\
\hline Childhood (2-12 years old) & 51 & $38.1 \%$ \\
\hline Teenager (13-17 years old) & 47 & $35.1 \%$ \\
\hline Adulthood (18-40 years old) & 36 & $26.8 \%$ \\
\hline \multicolumn{3}{|c|}{ Frequency of Violence Exposure } \\
\hline Once & 29 & $21.6 \%$ \\
\hline More than Once & 105 & $78.4 \%$ \\
\hline \multicolumn{3}{|l|}{ Violence Perpetrators } \\
\hline Known & 115 & $85.8 \%$ \\
\hline Strangers & 19 & $14.2 \%$ \\
\hline \multicolumn{3}{|l|}{ Violence Continuation } \\
\hline Already over & 115 & $85.8 \%$ \\
\hline Still ongoing & 19 & $14.2 \%$ \\
\hline \multicolumn{3}{|c|}{ Accessing Post-incident Treatment } \\
\hline Yes & 8 & $6.0 \%$ \\
\hline No & 126 & $94.0 \%$ \\
\hline \multicolumn{3}{|l|}{ Disclosure to Others } \\
\hline Yes & 77 & $57.5 \%$ \\
\hline No & 57 & $42.5 \%$ \\
\hline
\end{tabular}

The result of LoC showed that there were no participants with a dominant internal LoC, so the data which related to internal LoC could not be processed. Using simple linear regression, it showed that external LoC contributes significantly to trauma resilience $(\mathrm{p}=.000$,
$\left.\mathrm{R}^{2}=.139\right)$. We also conducted analysis tests on participant demographic data. This analysis showed a significant difference in score $(p<0.05)$ on experience of violence, the perpetrators and whether participants shared the violence experienced with others or not.

Table 2

Simple Linear Regression

\begin{tabular}{lccccc}
\hline & \multicolumn{3}{c}{ External LoC } & \\
& $\mathrm{R}$ & $\mathrm{R}^{2}$ & $\mathrm{~B}$ & Std. Error & $\mathrm{t}$ \\
\hline Constant & .372 & .139 & 189.211 & 11.804 & 16.029 \\
Total External & & & 3.173 & .688 & 4.610 \\
LoC & & & & \\
\hline
\end{tabular}




\section{RIZKIA \& KUSRISTANTI}

\section{Table 3}

Demographic Data with Trauma Resilience

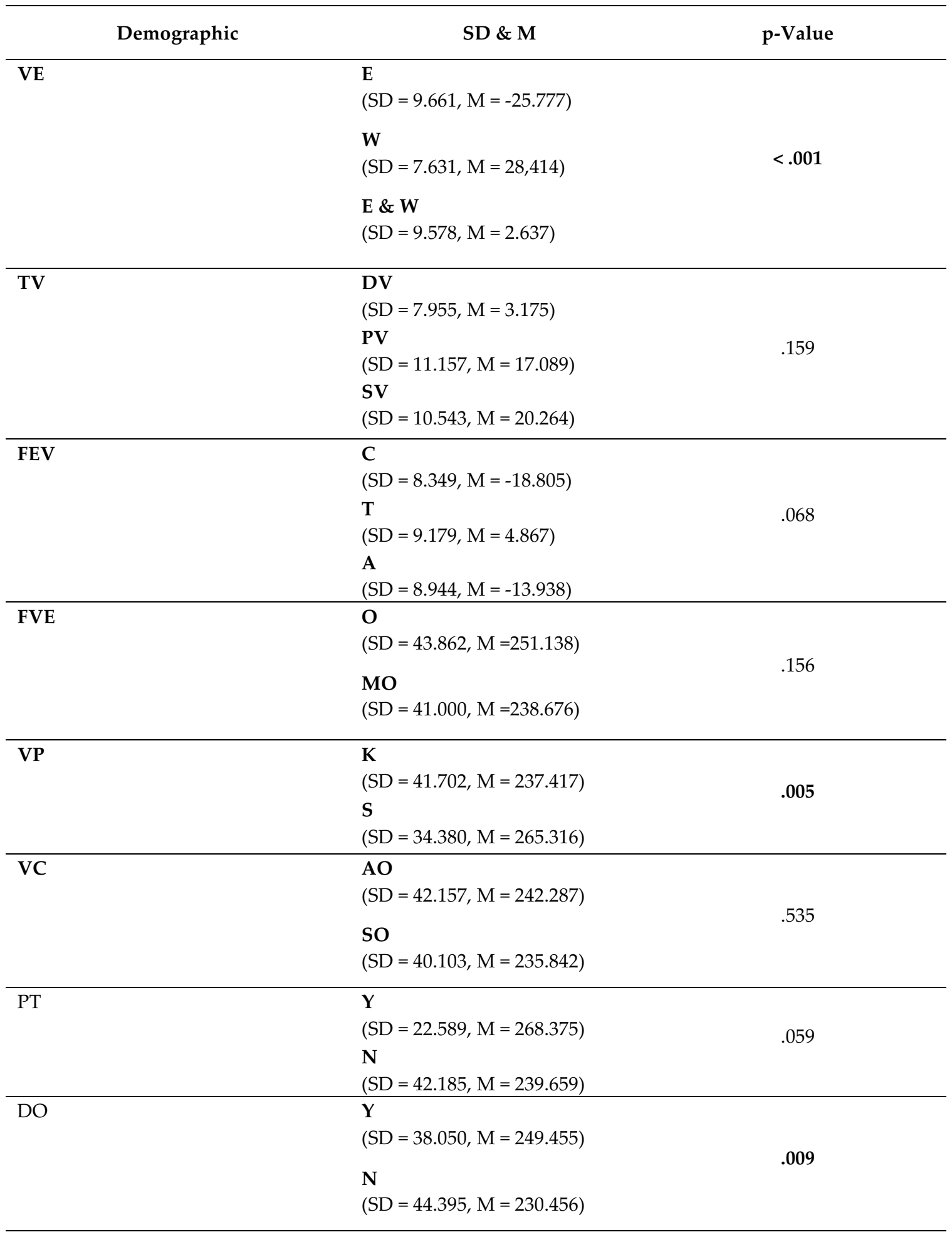

Note on Table 3. SD = Standard Deviation; $\mathrm{M}=$ Mean; VE = Violence Exposure; $\mathrm{E}=$ Experienced; $\mathrm{W}=$ Witnessed; TV = Type of Violence; DV = Domestic Violence; PV = Physical Violence; SV = Sexual Violence; FEV = First Exposure to Violence; $\mathrm{C}=$ Childhood; $\mathrm{T}=$ Teenager; $\mathrm{A}=$ Adulthood; FVE = Frequency of Violence Experience; $\mathrm{O}=$ Once; $\mathrm{MO}=$ More than Once; $\mathrm{VP}=$ Violence Perpetrators; $\mathrm{K}=$ Known; $\mathrm{S}=$ Strangers; $\mathrm{VC}=$ Violence Continuation; $\mathrm{AO}=$ Already Over; $\mathrm{SO}=$ Still Ongoing; $\mathrm{PT}=$ Post-incident Treatment; $\mathrm{DO}=$ Disclosure to Others; $\mathrm{Y}=$ Yes; $\mathrm{N}=\mathrm{No}$. 
Furthermore, statistical tests using Post-hoc Tukey and t-test showed that the average resilience of trauma was significantly higher in participants who had witnessed violence $(\mathrm{M}=28,414, \mathrm{SE}=$ 7,631), Ptukey <.001 compared with other two groups, those who experienced violence $(M=-25.77, S E=9,661)$ Ptukey 0.023 and those who experienced and witnessed violence $(M=2,637, S E=9,578)$, Ptukey 0.959. Different test with t-test is carried out on demographic data, which is the perpetrators of violence. The t-test results showed that the average of trauma resilience was significantly higher in participants who witnessed or experienced violence committed by strangers $(M=265,316, S D=34,380)$ than participants who were exposed to violence perpetrated by people known (M $=236,348, \mathrm{SD}=41,663)$.

Other test using t-test showed that the average trauma resilience was significantly higher in participants who told other about the violence that they experienced or witnessed $(\mathrm{M}=249,455$, $\mathrm{SD}=38,050)$ compared to participants who did not tell others about the violent events $(\mathrm{M}=230,456, \mathrm{SD}=44,395)$.

\section{Discussion}

This study shows two results. First, there is a significant role of external $\mathrm{LoC}$ in trauma resilience among young women exposed to violence. Furthermore, participants with a dominant external LoC indicated that they had low trauma resilience. Second, it is also found that three demographic data show significant differences in trauma resilience. Those demographic data are violence exposure, perpetrators, and their disclosures about the violent incidents they were exposed to. In other words, both hypotheses are proved.

The role of external LoC on trauma resilience similar with the research result by Specht, Egloff, and Schmukle (2011). In a study using individuals who had been experienced trauma due to the death of their closest person as the sample, it was found that in stressful situations, people who have more dominant external LoC tend not experiencing a decrease in life satisfaction. This is because people understand that the existence of things cannot be controlled by themselves and encourage theirselves to accept their 
powerlessness. Other studies also explain the function of external LoC related to trauma contexts. A study conducted by Mellon, Papanikolau, and Prodromitis (2009) focuses on people who had experienced trauma due to natural disasters, which shows that they had more dominant external LoC. They could provide social support to themselves and others more effectively. They assumed that everyone needs support from others when traumatic situations happened, which leads to provide emotional support to others and hope that they would receive that support back.

However, both studies mentioned earlier did not fit the context of trauma experienced caused by violence due to the different nature of trauma experienced by participants of both studies. Both research results show the contribution of external LoC only explain when people are in a state of trauma in the context of events beyond their power, for example, the death of their significant others and natural disaster. Meanwhile, violent incidents are the type of trauma that is not entirely beyond their power. Therefore, the dominance of internal $\mathrm{LoC}$ in women who had been exposed to violence is needed more than external LoC.
The dominance of internal LoC in women who are victims of violence also plays a role in increasing trauma resilience. Valentine and Feinauer (2007) stated that women who have experienced sexual violence during their childhood explained that internal LoC is one of the factors that can make them survive with their past experiences. Some participants indicated that they are aware of personal power within themselves, for instance, being able to say "no" or "stop" to something they perceive as a threat.

The results of this study are different from previous studies due to the role in internal LoC on trauma resilience could not be investigated. Several reasons could be used to explain why there are no participants with dominant internal LoC in this study. One of them is because this research is conducted in Indonesia. As a country heavily influenced by Eastern culture, there are some potential differences caused by cultural differences compared to Western countries, where the studies are usually conducted in. Stapleton and Yamaoka (2015) stated that there are some differences in ways of thinking and actions between people from Eastern culture and Western culture. In Eastern culture, people tend to accept 
good or bad events easily and also tend to obey and follow others rather than making their own decisions. In contrast, people in Western culture tend to be more aggressive and more determined to make their own decisions.

Another results that could explain why majority of participants reported to have a more dominant external LoC is related with age. Roazzi, Attili, Pentima, and Toni (2016) stated that LoC in individuals would also develop into an internal LoC as people get older. So, there is a possibility that participants possess a dominant external LoC because the average participants age was 22 years old.

In this study, other analyses used to investigate the differences in trauma resilience and LoC from demographic variables. In One-Way ANOVA analysis, it was found that women who only witnessed violence reported higher resilience compared to other categories (experienced violence firsthand, and both experienced as well as witnessed violence). Spilsbury, Kretschmar, Drinkard, and Flannery (2007) stated that people who saw or heard a violence incident would have a lower chance of trauma compared to people who were directly experiencing violence. The research explained that people who only saw or heard violence are not directly exposed to violence, so the impact is indirect and smaller compared to people who experienced violence directly. This caused them to have a smaller chance of developing trauma compared to people experiencing violence directly.

Another result using an independent $\mathrm{T}$-test found that trauma resilience scores showed some significant differences if viewed from violence perpetrators. Ungar (2013) explained that resilience found to be diverse, or there are some variations in each individual. This study found that people who were violated by someone they know are reported to have lower trauma resilience compared with people who were exposed to violence done by strangers. If victims violated by people they know, they will interpret the violence as a manifestation of an insecure world and would not have protection or proper treatment. In the same study, it was explained that if violence done by people they know, the chance of violence frequency also increases. This will have an impact as that they will assume their environment is not a safe place.

Furthermore, another test using independent T-test showed a significant difference in trauma resilience between 


\section{RIZKIA \& KUSRISTANTI}

participants who reported or told others about their violence incident and those who did not. Participants who told others about the incident reports higher trauma resilience compared to participants who did not tell others about the incidents. A

study conducted by Phillips and Vandenbroek (2014) with participation from domestic violence victims conveyed that usually, women who reported the violence incidents have a feeling of hope. Specifically, they hope to escape from that horrifying situation. Such hope is from their belief that they can gain support from others. Masson, Benoudji, Reyes, and Bernard (2017) stated that one of the processes commonly performed by women survivors is to seek social support.

Ahlin (2014) explained that people with dominant external LoC and receive reinforcements from others tend to give strength to themselves. Usually, people are not brave enough to tell about their violence experienced by others due to fear of being blamed by other people (O'Flaherty, 2019). Therefore, the same study also mentioned that people who told others (therapists, family, or significant others) about their violence experienced tend to have adequate trauma resilience.
The implication of this study is none of the participants had a more dominant internal LoC, so this study could explain the internal LoC. Besides, this research did not a questionnaire to measure participants' trauma, so it cannot be known the level of traumatic experienced. In other words, this research could not focus on the trauma level, so the research could not conclude the impact of level of trauma on LoC. For future research in this field, it is better to add a questionnaire aims to measure participants' trauma.

One advantages of this study is the ability to explains the factors that could affect LoC and trauma resilience by using statistical tests on participant demographic data. The demographic data including people with violence exposure, whether they experiencing it, witnessing it, or both; the type of violence including domestic violence, physical violence, sexual violence, or more than one type; the duration of first exposure to violence, including first experience in childhood, teenager, or adulthood; the frequency of violence exposure; the violence perpetrators; the violence continuation; the access to post-incident treatment; and telling others about their violence experienced. This result of the research is 
unique because $100 \%$ of participants have external LoCs.

There are also more detailed results. It is found that participants who only witnessed violence had a lower trauma resilience, particpants who experienced violence from strangers had a higher trauma resilience, and participants who told others about their experience of violent incidents had a higher trauma resilience. To conclude, those results showed that the second hypothesis is accepted. Another advantage is that the sample in this study is specific, which were women violence victims in Indonesia, while there are only a few studies that focuses on violence against women in Indonesia.

\section{Conclusion}

The results of this study indicate that external LoC significantly influenced trauma resilience. It also shows that participants with more dominant external LoC tend to have low trauma resilience. Related to demographic variables, results show that trauma resilience is found to be higher among participants who only witnessed violence, who were exposed to violence by strangers, and who disclosed the violent incidents they were exposed to someone they trust. All in all, the results indicate that both hypotheses are accepted.

\section{Implication}

There are several implications from this study. First, because none of the participants reported a more dominant internal LoC, it is highly suggested that future studies should focus on women who were exposed to violence with a dominant internal LoC. Second, the results can be used as an additional information in establishing an effective intervention for women who were exposed to violence, more specifically about the contribution of external LoC in building resilience.

\section{References}

Ahlin, E. M. (2014). Locus of Control Redux: Adolescents' Choice to Refrain From Violence. Journal of Interpersonal Violence, 29(14), 26952717.

https://doi.org/10.1177/088626051352 0505

Alho, C. M. (2015). The social effects of the exposure to domestic violence during childhood: A SocioEducational Perspective. Africa: University of South Africa.

American Pscyhological Association. (2019). The road to resilience. Retrieved from www.apa.org: https://www.apa.org/helpcenter/roa d-resilience

Anderson, K. M., Renner, L. M., \& Danis, F. S. (2012). Recovery: Resilience and Growth in the Aftermath of 
Domestic Violence. Violence Against Women, 18(11), 1279-1299. https:// doi.org/10.1177/1077801212470543

Asberg, K., \& Renk, K. (2014). Perceived stress, external locus of control, and social support as predictors of psychological adjustment among female inmates with or without a history of sexual abuse. International Journal of Offender Therapy and Comparative Criminology, 58(1), 59-84. https://doi.org/10.1177/0306624X1246 1477

Burt, K. B., \& Paysnick, A. A. (2012). Resilience in the transition to adulthood. Development and Psychopathology, 24(2), 493-505. https://doi.org/10.1017/S09545794120 00119

Carlson, E. B., \& Dalenberg, C. J. (2000). A Conceptual Framework for the Impact of Traumatic Experiences. Trauma, Violence, \& Abuse, 1(1), 4-28. https://doi.org/10.1177/152483800000 1001002

Cazan, A.-M., \& Dumitrescu, S. A. (2016). Exploring the relationship between adolescent resilience, self-perception and locus of control. (September), 283-286. https://doi.org/10.15303/rjeap.2016.si 1.a61

Collins, A. M., \& Swearer, S. M. (2012). Dating violence. School Psychologist.

Domhardt, M., Münzer, A., Fegert, J. M., \& Goldbeck, L. (2015). Resilience in Survivors of Child Sexual Abuse: A Systematic Review of the Literature. Trauma, Violence, and Abuse, 16(4), 476-493. https://doi.org/10.1177/152 4838014557288

Dyson, J., Cobb, M., \& Forman, D. (1997). The meaning of spirituality: a literature review. Journal of Advanced Nursing, 26(6), 1183-1188. https://doi. org/10.1111/j.1365-2648. 1997.tb00811 . $\mathrm{x}$
Hood, S. K., \& Carter, M. M. (2008). A preliminary examination of trauma history, locus of control, and PTSD symptom severity in African American women. Journal of Black Psychology, 34(2), 179-191. https://doi.org/10.1177/009579840731 0541

Huntley, F. L., Palmer, E. J., \& Wakeling, H. C. (2012). Validation of an adaptation of levenson's locus of control scale with adult male incarcerated sexual offenders. Sexual Abuse: A Journal of Research and Treatment, 61.

Jamison, L. (2016). Depression and resilience among young adult colleges students with varying victimization experiences. Research Gate.

Madsen, M. D., \& Abell, N. (2010). Trauma resilience scale: Validation of protective factors associated with adaptation following violence. Research on Social Work Practice, 20(2), 223-233. https://doi.org/10. 1177/1049 731509347853

Masson, V. L., Benoudji, C., Reyes, S. S., \& Bernard, G. (2017). Violence against women and girls and resilience. French: Braced Knowledge Manager.

Masten, A. S., Burt, K. B., Roisman, G. I., Obradović, J., Long, J. D., \& Tellegen, A. (2004). Resources and resilience in the transition to adulthood: Continuity and change. Development and Psychopathology, 16(4), 1071-1094. https://doi.org/10.1017/S0954579404 040143

Mellon, R. C., Papanikolau, V., \& Prodromitis, G. (2009). Locus of control and psychopathology in relations to levels of trauma and loss: self reports of Peloponnesia 
wildfire survivors. Journal of Traumatic Stress, 193-195. doi:10.1002/jts.20411.

Memmi, D. (2017). Comparative foundations of Eastern and Western thought. AI and Society, 32(3), 359368. https://doi.org/10.1007/s00146016-0656-5

Moya, A. (2018). Violence, psychological trauma, and risk attitudes: Evidence from victims of violence in Colombia. Journal of Development Economics, 131, 15-27. https://doi.org/ 10.1016/j.jdeveco.2017.11.001

O'Flaherty, M. (2019). Women as victims of partner violence: Justice for victims of violent crime part IV. Belgium: European Union Agency for Fundamental Rights.

Phillips, J., \& Vandenbroek, P. (2014). Domestic violence in Australia: an overview of the issues. Parliamentary Library Research Paper, (October), 42. Retrieved from http://parlinfo.aph. gov.au/parlInfo/download/library/pr spub/1246402/upload_binary/124640 2.pdf;fileType=application/pdf\#searc $\mathrm{h}=\%$ 22background note (parliamen tary library, australia) $\% 22 \% 5 \mathrm{Cn}$ http ://agent.capmon.com/facsnet/cgi-bin /facsserve_document.cgi/facs/p

Roazzi, A., Attili, G., Di Pentima, L., \& Toni, A. (2016). Locus of control in maltreated children: The impact of attachment and cumulative trauma. Psicologia: Reflexao e Critica, 29(1). https://doi.org/10.1186/s41155-0160025-9

Rotter, J. B. (1966). Generalized expectancies for internal versus external control of reinforcement. Psychological Monographs: General and Applied, 1.

Specht, J., Egloff, B., \& Schmukle, S. C. (2011). The benefits of believing in chance or fate: External locus of control as a protective factor for coping with the death of a spouse. Social Psychological and Personality Science, 2(2), 132-137. https://doi.org /10.1177/1948550610384635

Spilsbury, J. C., Belliston, L., Drotar, D., Drinkard, A., Kretschmar, J., Creeden, R., ... Friedman, S. (2007). Clinically significant trauma symptoms and behavioral problems in a community-based sample of children exposed to domestic violence. Journal of Family Violence, 22(6), 487-499. https://doi.org/10.10 07/s10896-007-9113-z

Stapleton, P. B., \& Yamaoka, T. (2015). Exploring the links between culture, locus of control and self-compassion and their roles in the formation of weight stigmatization. The New School Psychology Bulletin, 13(2), 3246.

Thureau, S., Blanc-Louvry, L., Thureau, S., Gricourt, C., \& Proust, B. (2015). Conjugal violence: A comparison of violence against men by women and women by men. Journal of Forensic and Legal Medicine, 42-46. doi:10.1016 /j.jflm.2014.12.014

Ungar, M. (2013). Resilience, Trauma, Context, and Culture. Trauma, Violence, and Abuse, 14(3), 255-266. https://doi.org/10.1177/152483801348 7805

Valentine, L., \& Feinauer, L. L. (2007). Resilience factors associated with female survivors of childhood sexual abuse. American Journal of Family Therapy, 21(3), 216-224. https://doi.org/10.1080/019261893082 50920https://doi.org/10.1080/0192618 9308250920

World Health Organization. (2012). Intimate partner violence - World Health Organization. Retrieved from apps.who.int: https://apps.who.int 


\section{RIZKIA \& KUSRISTANTI}

/iris/bitstream/handle/10665/77432/W

HO_RHR_12.36_eng.pdf;jsessionid=F

D3A40189FF08302C20F61B4BCE3FD

$\mathrm{C} 2$ ? sequence $=1$ 